\title{
SOY AND DEVELOPMENTALIST PERCEPTIONS: THE EVOLUTION OF EXPORT-ORIENTED AGRICULTURE AND THE GROWTH OF SOY THROUGH STRUCTURAL TRANSFORMATIONS OF THE BRAZILIAN STATE
}

\author{
Niels Sondergaard
}

\begin{abstract}
The goal in the following article is to understand how the soy sector, as part of export-oriented agriculture, has evolved through the different developmental stages in the Brazilian economic history of the $20^{\text {th }}$ and early $21^{\text {st }}$ century, and how the country's shifting insertion into the global market has positioned interests linked to this sector, in relation the political hegemony of the day. The pragmatic nature of the policies addressing export agriculture is initially traced from the early developmentalism, through the birth of soy cultivation in the latter half of the century, towards the day today, when this single crop has come to hold an extremely significant position within Brazilian exports; a position which has had strong repercussions within the political sphere. A strong emphasis is laid upon the structural transformation of the Brazilian economy in the 1990's and the new panorama which its internationalization has created for the growth of the soy sector, both during the Cardoso and the Lula administration. Different developmentalist visions, both in their historical conceptualizations and in their presence within the contemporary political scenario through a neo-developmentalist orientation, are synthesized with significant developments within export-agriculture, in order to understand how they in praxis have come to concede a favorable political positioning of rural bourgeoisie. It thereby assumes the character of a historical analysis of the political economy of agricultural policies, with a particular focus upon the evolution of the soy sector. The article concludes that Brazils historical positioning within the global economic scenario has at the most, made it possible to mitigate the political influence of export-agriculture, which has been a constantly significant factor, restricting the possibilities for social inclusion of destitute rural segments and exacerbating the sub-ordinate positioning as a raw material exporter. The "long perspective" which this paper operates with, derives from the perception of the need to understand the profound development which the soy expansion in Brazil during recent decades has constituted, by tracing the policies affecting this sector below the imperatives posed by the structural transformations of the Brazilian economy.
\end{abstract}

Keywords: soy, developmentalism, neo-developmentalism, agriculture, raw materials

\section{Resumo}

O objetivo deste artigo é entender como o setor de soja, como parte de uma agricultura orientada para a exportação, evoluiu ao longo dos diferentes estágios de desenvolvimento na história econômica brasileira do século 20 e início do século 21, e como a inserção do país no mercado global tem posicionado interesses ligados a este setor, em relação à hegemonia política atual. A natureza pragmática das políticas destinadas à agricultura de exportação é inicialmente traçada desde o início do desenvolvimentismo, passando pelo nascimento de cultivo da soja na segunda metade do século, até os dias atuais, quando esta única cultura ganhou uma posição extremamente importante dentro das exportações brasileiras; uma posição que tem tido fortes repercussões na esfera política. Uma forte ênfase é colocada sobre a transformação estrutural da economia brasileira na década de 1990 e do novo panorama de internacionalização, que criaram as bases do

${ }^{1}$ Master in Global Studies and Political Science, Lund University (Sweden) 
crescimento do setor da soja, tanto durante os governos de Cardoso quanto de Lula. Diferentes visões desenvolvimentistas, tanto em suas concepções históricas e em sua presença no cenário político contemporâneo, por meio de uma orientação neo-desenvolvimentista, são sintetizados como elementos significativos dentro de agricultura de exportação, a fim de entender como eles, na prática, têm vindo a conceder um posicionamento político favorável à burguesia rural. Assim, assume-se o caráter de uma análise histórica da economia política das políticas agrícolas, com um foco particular sobre a evolução do setor de soja. $\mathrm{O}$ artigo conclui que o posicionamento histórico brasileiro dentro do cenário econômico mundial, no máximo, permitiu reduzir a influência política da agricultura de exportação, que tem sido um fator significativo constante, restringindo as possibilidades de inclusão social de segmentos rurais carentes e exacerbando o posicionamento subordinado como um exportador de matéria-prima. A " perspectiva de longo prazo", com a qual este artigo trabalha, deriva da percepção da necessidade de compreender o desenvolvimento profundo da expansão da soja no Brasil nas últimas décadas, traçando as políticas que afetam esse setor sob os imperativos colocados pelas transformações estruturais da economia brasileira.

Palavras-chave: soja, desenvolvimentismo, neo-desenvolvimentismo, agricultura, material-prima.

\section{Resumen}

El propósito de este artículo es comprender cómo el sector de la soja, en el marco de una agricultura orientada a la exportación evolucionado a lo largo de las diferentes etapas de desarrollo en la historia de la economía brasileña del siglo 20 y principios del siglo 21, y de cómo la inserción del país en mercado mundial se ha posicionado intereses vinculados a este sector, en relación con la hegemonía política actual. La naturaleza pragmática de las políticas destinadas a la agricultura de exportación se dibuja inicialmente desde el inicio del desarrollismo, a través del nacimiento del cultivo de soja en la segunda mitad del siglo hasta nuestros días, cuando esta cultura única ganó una posición muy importante dentro de las exportaciones brasileñas; una posición que ha tenido fuertes repercusiones en la esfera política. Un fuerte énfasis se pone en la transformación estructural de la economía brasileña en la década de 1990 y el nuevo panorama de la internacionalización, que sentó las bases para el crecimiento en el sector de la soja, tanto de los gobiernos Cardoso y Lula. Diferentes visiones de desarrollo, tanto en sus concepciones históricas y su presencia en la escena política contemporánea, a través de una orientación neo-desarrollista, se sintetizan como elementos importantes dentro de la agricultura de exportación con el fin de entender cómo, en la práctica, han sido conceder posición política favorable a la burguesía rural. Por lo tanto, asume el carácter de un análisis histórico de la economía política de las políticas agrícolas, con un enfoque particular en la evolución de la industria de la soja. El artículo concluye que la posición histórica de Brasil en el escenario económico mundial, el máximo permitido para reducir la influencia política de la agricultura de exportación, lo cual ha sido un factor significativo constante limitan las posibilidades de inclusión social de los sectores rurales pobres y exacerba la posición subordinada como exportador de materias primas. La "perspectiva a largo plazo", con la que trabaja este artículo se deriva de la necesidad percibida de comprender el profundo desarrollo de la expansión de la soja en Brasil en las últimas décadas, trazando políticas que afectan a este sector bajo los imperativos de las transformaciones estructurales economía brasileña.

Palabras clave: soja, desarrollismo, neo-desarrollismo, agricultura, materias primas. 


\section{HISTORICAL ORIGINS OF DEVELOPMENTALISM AND THE POSITIONING OF RURAL INTERESTS}

From the point when Getúlio Vargas reached power as a result of the Brazilian revolution of 1930, the push towards industrialization of the country meant that a proindustrial bias became an integrated part of official policies. At the core of the new developmentalist coalition was the industrial bourgeois, which to a high degree came to displace the previously dominant landholder class. The fundamental goal of the nationaldevelopmentalist orientation of the new governing coalition was articulated as the profound transformation of the country's politico-economic and social structure, from a heavy dependency upon a short range of agrarian export commodities, - at the time predominantly coffee - towards an industrialized society (FONSECA; HAINES, 2012 p. 1049; PRADO, 2008, p.22; GONÇALVES, 2012, pp 649-552).

The state was positioned as a central agent within the Brazilian developmentalism of the $20^{\text {th }}$ century as a planner, inducer and creditor, fomenting the industrial modernization of the country, all the while drawing its legitimacy from the perceived social imperatives of lifting the country out of its historical underdevelopment (MOLLO; FONSECA 2013, p.224). The developmentalist mission became so intrinsically intertwined with the state's razon de être and embedded within its institutions during the Vargas era, that in spite of variation in the ideological superstructure of shifting democratic and authoritarian governments since then, it continued to define the politico-economic base of the Brazilian society until changes in the international economic scenario forced a fundamental transformation upon this system, in the course of the 1980's and 1990's (SALLUM, 1999, p.25).

The developmental project angled towards industrialization and the long term goal of diminishing primary commodity dependence, also came to draw academic and ideological support from the ECLA (From 1984 ECLAC, - Economic Commission for Latin America and the Caribbean) which became highly significant in influencing Latin American developmental discourses of the post-war decades. Within this theoretical framework, the historical underdevelopment of Latin America was closely connected to the issues of declining terms of trade for raw materials in relation to manufactures, prolonged external deficits and inadequate technological acquisitions (PREBISH, 1950, p.8; MAÑAN, 2010, p.11.)

Yet, as the Brazilian developmentalist project unfolded, both in the Vargas years 
and after that, national development was not defined in complete contrast to the continued export performance and modernization of the agricultural sector. The main preoccupation with the agricultural sector during that early period was with the heavy reliance upon an extremely limited range of agricultural export commodities, and with the lack of links to domestic elaboration to ensure economic spillover effects from such activities (FONSECA; HAINES, 2012, p.1046 \& 1049).

The income from agricultural exports continued to form a solid base of external revenues, which proved to be necessary in order to finance the ongoing process of industrialization. This led to a very peculiar situation, in which considerations related to this sector's performance could not be neglected, and as a consequence, the rural bourgeois also maintained a certain degree of political influence, in the outskirts of the ruling coalition. Hereby, the same labor legislation which had benefitted the urban working class and made it support the developmentalist coalition, was not extended to rural workers, largely resulting in a sustainment of rural status quo, privileging the class of landowners. (COELHO, 1991, pp.203-204, 206; FONSECA; HAINES, 2012, p.1052)

The Brazilian developmentalist experience from the $20^{\text {th }}$ century thereby comes to reflect a sort of double-edged relation to the country's historical situation of raw material dependence: on the one hand, the rural bourgeois is displaced from a hegemonic position within the state and a project is launched, with the goal of structurally upgrading the country's positioning within the world economy, through industrialization and modernization. On the other hand, a sort of pragmatically rooted acceptance of the very real imperatives of the structural insertion into the global economy at the given time, is reflected in the a strategically co-opting of a part of the export capable rural bourgeoisie into the governing coalition, though below the general developmental project defined by the new hegemonic actors. The principled aversion towards raw materialism and its multiple societal implications is expressed through the long term project of industrialization. Yet, the indispensability of these export commodities as a basic source of revenues for a country with an immediate potential for primary material exports, is reflected in the short term neglect of introducing social regulation of the agricultural sector.

\section{SYSTEMIC TRANSITION AND SOY EXPANSION}

Towards the end of the 1970's and at the beginning of the 1980's, the developmentalist model based upon a significant state intervention began to approach the limits of its structural capacity, a tendency which was further exacerbated when interest 
rates soared from 1979, leading towards the Latin American debt crisis of 1982. In the Brazilian context, the ensuing economic instabilities engendered a movement leading towards a profound restructuring of the country's economy, in the direction of a neoliberal inspired model, characterized by the retraction of the state from many vital economic areas. This process would be consolidated in the mid 1990's with the election of Fernando Henrique Cardoso (SALLUM 1999, p. 25, 31; 2003, pp.42-44)

This transformation also wielded a profound impact upon the Brazilian agriculture and the growth prospects of export-oriented sectors within this, - particularly soy. Since soy had at first been cultivated in Brazil in the 1960's, the sector had been the object of a high degree of public attention as strategically important for national food security and the alimentary industry. This meant that a large amount of economic and technological recourses were channeled into the soy sector in form of various types of subsidies, but also that it was subjected to a range of price controls and restrictions for international commercialization, which are generally believed to have limited its export potential (WARNKEN, 2002, p.54, 63).

The new structural imperatives below the neoliberal order of the day are emphasized by Mañan as monetary equilibrium, external openness, incentives for private accumulation and market freedom (MANAN, 2010, p.19). Sallum pinpoints more specifically about the metamorphosis of the state during the Cardoso presidency, that the principle changes in its nature can be characterized as a whole or partial withdrawal from functions which can be performed by private actors, through its new rigid engagement with ensuring fiscal balances and with the facilitation of commercial interaction with the exterior (SALLUM ,1999, p.31). These changes all came to define a new role for export-oriented agriculture and for the soy sector. Some of the most profound changes which soy agriculture underwent came in form of the dismantling of the public subsidy schemes, the commercial liberalization, and the opening of the economy as indirect consequences of the monetary stabilization efforts through Plano Real (DELGADO, 2008, p.28). With the withdrawal of the state, the Brazilian soy sector entered a period of an unprecedented low degree of governmental intervention (WARNKEN, 1999, p.79).

As a prerequisite of the Mercosul and WTO agreements which Brazil entered during this period, governmental subsidies for domestic agricultural production needed to be significantly reduced (CASSEL; PATEL, 2003, pp.23-24). This resulted in strong reductions within public credit programs targeting agriculture and also implied the 
substitution of price guarantee schemes with cheaper and less comprehensive programs (COELHO, 1999, p.13). The cuts in rural credits also became evident through the abandoning of publically guaranteed low interest loans. Loans from private creditors were hereafter mainly available to larger rural estates capable of providing sufficient collateral and which financially were better prepared for enduring the years with high interest rates (CASSEL; PATEL, 2003, pp.24-25). The cuts in public support also made farmers more dependent upon selling their products at the international market, which in a domestic context favored export-oriented agriculture, such as the soy sector (BERALDO, 2000, p.3).

The credit reduction measures of the 1990's were also markedly stronger in the case of crops which were widely consumed domestically, than in the case of export crops: wheat and rice underwent strong subsidy reductions while soybeans were exposed to much lower aggregate cuts (CASSEL; PATEL, 2003, p.24). In 1996 soybeans, including subproducts, were exempt from payment of the ICMS (an internal circulation tax), which led to higher profits for producers as well as a significant surge in exports (WARNKEN, 1999 p.78).

The implementation of the Plano Real also had a strong impact upon Brazilian agriculture, through the valorization of the real exchange rate until 1997 and through the generally elevated interest rates (DELGADO, 2008, p. 19). Yet, the negative effects of these measures were partially offset by a hike in global prices for soybeans and other export-crops towards the end of the 1990's. (DE MELO, 1999, p.148). The devaluation of the Real from 1999 also diminished the negative impact which high exchange rates were wielding upon soy exporters (Ibid, 1999, p.155). Consequentially, the effects which the economic structural transformation of the Brazilian state wielded upon the agricultural sector, through the combination of reduction of public subsidies for domestic agriculture, high interest rates as part of the Plano Real, the impacts of trade liberalizations and commercial opening, came to exacerbate some already significant rural divisions, to the clear advantage of export-oriented agriculture, and particularly soy, vis-à-vis smallholder crops.

Through the re-vitalization of the prospects for agro-exporters during the Cardoso years, this class of landholders, or large-scale agro-exporters, also obtained a political positioning which was closer aligned with the hegemonic actors of the time. This can partly be understood through the simple necessity, which the imperatives of fiscal discipline and sound external balances implied within the new economic panorama. Regardless of this, the change in the orientation of the rural bourgeois must also be 
considered; from earlier seeking inwards protection in the developmentalist project, towards demanding external openness in order to be able to reap the benefits of expanding global markets and foreign capital investment, which further spurred the momentum of the structural transformation (SALLUM, 1999, p.26). Hereby, this alignment of rural and urban capital interests around a consensus of internationalization meant that a more thorough international engagement was made possible, - as demonstrated through the accession of Brazil in the WTO. Hereby, the movement away from the "classical" developmentalism had made it possible for dominant rural classes, to take a step closer towards the center of the hegemonic constellation at the time.

The association between the increasing weight of export-oriented agriculture as a sector/class on one hand, and the soyfication of Brazil on the other, is evident through the dramatically increasing relative and absolute share of both agricultural production as well as exports, which this single economic activity came to constitute, as a consequence of liberalization of the Brazilian agriculture. The total value of soy exports increased from US $\$ 808$ million in 1992 to US $\$ 4.29$ billion, in 2006 (FAOSTAT, 2014). At the turn of the millennium, soy had also become the principle agricultural export commodity, and the process of concentration of exports has continued up until the day today, when soy stands as the undisputedly most important agricultural export commodity, reaching a total value of US $\$ 23$ billion (ITC, 2013). In the same period, soy cultivation nearly doubled from occupying $21 \%$ of the total area dedicated to temporary crops in 1992, to cover $36 \%$ of this area in 2003 (IBGE 2013 - Producão Agricola Municipal). Hereby, the liberalization trends within the structural transformation of the Brazilian economy appear to have been closely intertwined with a tendency of export-orientation, which furthermore has spurred a process of product concentration, in which soy has been the predominant component. The mere weight which the soy sector gained within the broader Brazilian agriculture during this period, thus makes it possible to consider it as an intrinsic part of Brazilian exportoriented agriculture and thereby also to understand the agency and interests of this sector/class, as fundamentally linked to the goal of ensuring favorable regulatory and economic framework conditions for the soy regime.

The abandonment of direct agricultural subsidies as part of the liberalizations, however, did not mean that the state ceased to be involved within the soy business. Rather, in line with the logic of the Washington consensus, its role shifted from internal protection, to seeking the optimal conditions for Brazilian agribusiness' insertion into the global 
market. Guaranteeing the interests of Brazilian agriculture at the international level, thus, became a central focus for the Brazilian diplomacy, thereby also cementing the approximation of rural interests with other hegemonic actors within the state machinery (SALLUM, 2003, p.47).

The international trade negotiations in the 1990's also spurred the articulation of a common agenda amongst Brazil's different rural interest groups, which subsequently came to influence policymakers' acting through negotiations. In the course of the Uruguay round, the Brazilian Agricultural and Livestock Confederation (CNA) began accompanying the negotiations, followed by a range of smaller sectoral interests' organizations. The Uruguay round negotiations from 1986 - 1994 below GATT gave way to the formation of the WTO, which Brazil joined in 1995 (CASSEL; PATEL, 2003, p.11). The WTO agreement, established in August 1994, was based upon reforms within three fundamental pillars; the reduction of domestic support, market access and price subsidies (RODRIGUES, 2006, p.37). The Uruguay round thereby represented a significant step in the direction of liberalization of agricultural markets. Brazil, which was within the group of developing countries, was obliged to reduce export subsidies and import tariffs with $24 \%$ and domestic price support with $13.3 \%$ through a compliance period of 10 years (CASSEL;PATEL, 2003, p.11). At this early stage, the rural interest's organizations participation in the negotiations, - which previously had been very limited - was characterized by a lack of coordination and their posture was mainly defensive (BERALDO, 2000, pp.3-4)

The Mercosul membership from 1991 also implied the reduction of public support for agriculture, along with the opening of markets within the group of signatories (Ibid 2003). This contributed to a large increase in international trade and agricultural exports, in a situation in which control with imports and exports had passed on to be regulated only by exchange rate and tariff instruments (BRAUN, 2007, p.41). Agricultural exports surged to nearly double during the period; from US $\$ 5.4$ billion in 1990 to US $\$ 10.1$ billion in 2001. Notably, the international integration had also created a climate in which the export of soybeans gained a large potential for growth (IBID, 2007, p.42).

In the late nineties, a series of agricultural interest groups created the Permanent Forum for International Agricultural Negotiations, defining mutual interests for Brazilian agriculture. In cooperation with the Brazilian Agricultural Ministry, a joint agenda for negotiations at the international level was formulated. Though Seattle 1999 produced small negotiation results, this became a landmark for Brazilian rural mobilization. Through 
strengthened organization and a strong common ground, rural interests significantly influenced the government's posture on a range of critical issues discussed within the WTO, regarding market access, internal assistance and export subsidies (BERALDO, 2000, p.4)

After concentrated efforts, Brazilian agribusiness had finally reached a point at which it had become capable of affecting international negotiations (IBID, 2000, p.9). Thereby, an indirect channel was also established for influencing the domestic regulatory framework through mandatory regulation. Beyond any considerations regarding the possible embedded ideological biases of international monetary and financial institutions, the trade negotiations did come to function as a forum within which the alliance between export-oriented agricultural interests could be cemented. The state came to participate actively within this process in order to improve the international market conditions for Brazilian agriculture. Thereby, a market oriented consensus was shaped between the state and export-agriculture, which was based upon the mutual interests in ensuring the optimal competitive position for Brazilian agro-exports, and particularly soy, which has endured until the day today.

\section{OFFICIAL POLICIES TOWARDS SOY DURING RECENT DECADES}

In the following part, the goal is to understand how the soy sector has developed below the Workers Party (Partido dos Trabalhadores or PT) government, of Lula Da Silva and later Dilma Rousseff, and particularly, with regards to the neo-developmentalist paradigm, the features of which some scholars have been able to trace within this period. Furthermore, attention is directed towards how the soy sector has been able to influence policymaking through its integration within the state, in effect of an increasing rural representation within the Brazilian legislative and executive bodies. In this regard, focus is directed towards the process of legalization of transgenic crops from 2003-2005, as well as the issues of agrarian reform.

The question as to which degree the PT governments of the $21^{\text {st }}$ century can be ascribed a neo-developmentalist character will probably stand as an object of scholarly debate for some time to come. Bresser-Pereira sustains that in spite of having made some steps in that direction, the neo-developmentalism has not yet become hegemonic in contemporary Brazil (BRESSER-PEREIRA, 2011, p.83). According to Ban (2012) the remnants of the neo-liberal policies adopted in the 1990's have merged with the neo- 
developmentalist currents, and produced what is referred to as a hybridity during the Lula government, below which the fundamental neo-liberal policy prescriptions are adhered to, whilst seeking to channel some of the recourses produced through a market-oriented development, towards increased redistribution (BAN, 2012, p.320). Goncalves adopts a similarly skeptical approach towards the developmentalist experiences below the Lula government, which this author characterizes as an inversion of the orientation of the $20^{\text {th }}$ century's developmentalism, serving to exacerbate the structural dependence of Brazil on a range of central economic parameters (GONCALVES, 2012, p.638).

What stands clear from the PT period is that the soy sector has continued to grow steadily, from a production of 51 million ton in 2003 to 81 million ton, in 2013 (IBGE 2013) (EMBRAPA, 2013). Apart from the significance of the international marketing conditions, with increasing global demand and continual technological developments within Brazilian agriculture, the soy sector has assumed a size which has meant that a favorable regulatory environment has been a fundamental requirement for the expansion of soy cultivation, since the turn of the millennium. In this regard, it becomes necessary to further analyze the PT government's agricultural policies with special attention towards any possible neo-developmentalist traits, in order to assess how this in praxis has come to affect the development of soy within Brazilian agriculture.

The legalization of transgenic soybeans came to stand as a case, in which an initial resistance of the PT government against the introduction of transgenic soy was substituted by a pragmatic adherence to commercial interests. In 1998, the first reports began to appear of transgenic soybeans being planted illegally in the Southern State of Rio Grande do Sul, after having been smuggled in from Argentina, where it had already been legalized (DARIOT 2007, p.28). In 2003, farmers who had been planting illegally began to pressure the government to legalize the cultivation and commercialization of transgenic soy, as these producers claimed that they otherwise would be subjected to substantial losses (Ribeiro 2003, p.1). In March 2003, great demonstrations were held in favor of legalization, which also made the Ministry of Agriculture pledge to start investigating the possibility of liberalizing legislation on the issue (DARIOT, 2007, p.152). In a context of great pressure from rural interests, but also from within parliament, the Temporary Measure 113, which permitted the commercialization of transgenic seeds until the $31^{\text {st }}$ of January 2004, was signed by Brazilian President, Lula da Silva (Medida Provisória No 113, 2003).

The temporary permission to commercialize transgenic soybeans did not put an end to the issue, but rather exacerbated the many-folded pressures for a permanent 
legalization. Short after the ballot, rural factions in parliament initiated a political campaign to remove the existing legal obstacles for a permanent legalization. The rural parliamentary faction - bancada ruralista, - which before then had been mainly associated with parties to the right in Brazilian politics, could now also muster support from centrist parties within the governing coalition, and even sympathizers from Lula's workers party, PT (ALENCAR, 2003). The continued pressures led to the adoption of the Temporary Measure 131 of Sept. 25 2003 , which further prolonged the period for legal commercialization of transgenic soy, to the $31^{\text {st }}$ of December 2004 (Medida Provisória $N^{o}$ 131, 2003).

The Temporary Measures 113 and 131 did not succeed in halting the expansion of cultivation with transgenic seeds, which hereafter came in high demand by farmers all over Brazil (FOLHA, 2003). The MP 113 in particular, - which was considered a partial victory for the proponents of legalization, - spurred farmers to continue planting illegally, expecting further future legal exemptions (DARIOT, 2007, pp.152-153). This led towards a situation in which broad segments of society, both those in favor and against legalization, demanded clarity on the issue and a new Biosecurity Law, - the basic legal framework regulating transgenic products (TAGLIALEGNA, 2005, p.8). After strong pressures from rural factions within parliament, international agribusiness and from elements within the governing coalition, the new Biosecurity Law was signed by President Lula da Silva on March 24, 2005 (CHRISTINA, 2005). A long range of the demands from pressure groups in favor of the legalization of transgenic products, were incorporated within the final version of the law (TAGLIALEGNA, 2005 p.78). With strong forces within the Lula government favoring the introduction of transgenics, the first authorizations for the legal use of transgenic soybeans could be given the same year. Thus, the process of legalization of transgenic crops came to stand as a significant case in which the economic imperatives of the day, made the ruling coalition accept the introduction of transgenic crops, benefitting large-scale agricultural interests ahead of smallholders, consumer agencies and environmental interests.

The election of a leftist government had also spurred hopes that the process of agricultural reforms and land entitlement for landless peasants - which had slowly been initiated under Cardoso - would be speeded up under Lula's presidency (CARVALHO, 2011, p.2). Some significant programs were launched, such as the Program for Enforcement of Family Agriculture (Pronaf), the Program for Sustainable Development in 
the Rural Territories (PDSTR) and the National Plan for Agrarian Reform (PNRA) (Ibid, pp.6-7). Yet, the agricultural policies of the Lula administration were strongly characterized by the intention of unifying two widely differing agricultural projects; one with focus upon supporting smallholders and landless peasants, and the other which was strongly focused upon fomenting the further expansion and export potential of Brazilian agribusiness, with the goal of vital revenue generation for maintenance and development of extensive social programs. This contradiction ultimately made it difficult to thoroughly implement the policies with a social profile in the rural context, especially the agrarian reforms and land redistribution, which lost momentum in the face of export-oriented monoculture. (ENGELMAN; GIL, 2012, p.6) .

Privately owned land in Brazil is therefore still characterized by a markedly unequal distribution. Table 1 below illustrates how the large group of small properties below 10 hectares, constituting nearly half of all rural properties, only accounts for $2.36 \%$ of private land holdings, while the marginal group of properties above 1000 hectares, owns $44.42 \%$.

Table 1: Extend and distribution of rural property

\begin{tabular}{|c|c|c|}
\hline $\begin{array}{l}\text { Table 1: Extend and } \\
\text { distribution of rural } \\
\text { property. }\end{array}$ & $\begin{array}{l}\text { Percentage of registered } \\
\text { properties. }\end{array}$ & $\begin{array}{l}\text { Total area of the } \\
\text { properties (hectares). }\end{array}$ \\
\hline Less than 10 hectares & $47.86 \%$ & $2.36 \%$ \\
\hline 10 to 100 hectares & $38.09 \%$ & $19.06 \%$ \\
\hline 100 to 1000 hectares & $8.21 \%$ & $34.16 \%$ \\
\hline $1000+$ hectares & $0.91 \%$ & $44.42 \%$ \\
\hline
\end{tabular}

Source: Brazil, IBGE, 2006

The rural Gini coefficient, referring to equality of land distribution, has likewise increased from 0,857 to 0,872 from 1995-2006, meaning an increased inequality in land distribution during the period comprising of the Cardoso presidency and the first Lula administration (BRAZIL, IBGE, 2006). The Brazilian Institute for Geography and Statistics ascribes much of the increase in land concentration to the surge in exportoriented farming and above all soy cultivation, - the expansion of the agricultural frontiers and the professionalization of agriculture (FOLHA, 2009). Though this development might 
immediately appear to be at odds with the policy of egalitarian oriented agrarian reforms, on the basis of which Lula was elected, they may better be understood through the choice of inserting landholders as ministers of agriculture and commerce, which led towards the prioritization of aggressive expansion of export-oriented agriculture (CARVALHO, 2011, p.6). Such circumstances also contribute to explaining the lack of implementation of the agrarian reform, PNRA, during the Lula period as well as the frustration amongst smallholders, landless peasants, quilombolas and indigenous movements, which this eventually gave birth to (ENGELMAN; GIL, 2012, p.7; CARVALHO, 2011, p.7).

The absence of land reform specifically and more socially oriented rural policies generally, appears to be rooted in the perception of the indisputable developmental importance of strengthening the external potential of the agricultural sector. This also gave way to the belief that the agrarian reform as a project had become superfluous; an idea which has spread to the ideological basis of certain policymakers in the ruling Workers Party, PT (ENGELMAN; GIL, 2012, P.6). Similar perceptions were expressed by Roberto Rodrigues, - minister of agriculture in the first Lula government from 2003 to 2006, - who as early as in 2001 pointed towards the danger in what he perceived as the "radicalisms" linked to the claims for agrarian reform. Rodrigues furthermore expressed the importance of agro-exports as a vital element in maintaining sound external balances as well as a firm belief in the potential of Brazilian agribusiness to lift the country closer to the developed world, through improved competitiveness (RODRIGUES, 2001, pp.8-10, 12). The same belief in the ineluctable necessity of a strong market - though in conjunction with a strong state - is expressed by Siscü (et al.) as a fundamental pillar of the new developmentalism. Together with a profound state mandated developmentalist strategy, the improvement of market conditions becomes necessary in order to "ensure continued high rate growth", which is seen as the only way to "reduce social inequality" (SISCÜ ET. AL., 2005, p.3). Though these visions are not particularly directed towards the Brazilian agriculture, they do in fact describe the role which agriculture has been granted in the developmenta 1 model of the $21^{\text {st }}$ century's Brazil, and the pragmatic relation to export-agriculture, which dates back even further. In a context of sustained global demand, the soy sector becomes a source of easily accessible revenues for redistribution and political support, while at the same time ensuring positive external balances. Therefore, the interests of rural sectors with a strong export potential have been heeded extraordinarily, and the mission of the "strong state" has been redirected towards supporting export-agriculture outwards, through international 
trade negotiations, and internally through direct involvement in supportive research and development activities and infrastructure provision. In the case of the PT, the party might have lost certain elements of its initial political support base amongst poor rural segments and certain environmentalists, yet, in an increasingly urbanized country, the electoral effects of increased economic redistribution have far overshadowed the consequences of these agricultural policies.

Importantly, Siscü (et al) emphasizes the need for a new developmentalist strategy to move beyond earlier times' aversion against a strong raw material reliance, and to rather focus upon maintaining stable capital accounts and to foment domestic enterprises' export potential (SISCÜ ET AL, 2005, pp.16-17 \& 19). Such neo-developmentalist perceptions constitute the central object of critique from authors who attack the lack of structural perspective, which is seen as the consequence of a one-sided attention to macroeconomic stability. Goncalves sustains that the consequence of the disengagement of the state with more specific developmental issues, means that a long range of developmental problems are overlooked, (GONCALVES, 2012, p.660) - problems which also are highly associated with the contemporary soy sector. Amongst these can be mentioned an extremely skewed distribution of income from soy cultivation and a rural property structure with increasingly unequal land tenure (SCHLESINGER, 2008, p.6), foreign ownership of a large part of the commercialization and patenting and lack of domestic elaboration activities (ALBANO \& DE SÁ, 2011, pp.65-66) external vulnerability due to high export concentration of soy products within the total export matrix (ITC 2013) and finally the disproportionate influence of rural interests in contemporary Brazilian politics (VIGNA, 2007, pp.13-14). The disregard to the issue of national capital involved within the various stages of production constitutes another significant difference, between "old and new" developmentalism, where in the later, this has passed on to become a "non-issue" (GONCALVES, 2012, p.659).

In another critical assessment of the neo-developmentalist perspective, Sampaio underlines the "economic reductionism" inherent in the lack of attention to the continued structural subordinate positioning within the world economy, which the contemporary reliance upon primary commodities implies (SAMPAIO, 2012, pp.81-82). The author claims that this is a product of a basic misperception that economic growth automatically mitigates social inequality, which is ascribed to the contemporary Brazilian neodevelopmentalism (Ibid 2012, p.679). In relation to the consequences of the dynamic expansion of the Brazilian soy production, such critique highlights the paradox inherent in 
the circumstance, that one of the main economic bases of the Brazilian economic development, is constituted by a detrimental mode of production, characteristic of a historically exploitative development, or in Frank's (1978) terminology; the development of underdevelopment.

In the contemporary scenario for global raw materials, with slowing demand for primary products, which has led some observers to conclude that the end of the commodity boom of the early $21^{\text {st }}$ century is near, the question about the danger of an exaggerated reliance upon a few all important export products becomes ever more pressing. This might point towards the relevance of isolating the non-implemented aspects of the contemporary neo-developmentalist academic perspectives, considered as a different line of though than the effectuated policies of the PT administrations of the recent decades, in order to shortly examine the alternatives visions which they offer. In the Ten Theses on New Developmentalism (2010), published by a group of Keynesian and Structuralist economists in São Paulo in 2010, the principle of "environmentally sustainable capital accumulation" is clearly mentioned, which in case it had to be effectuated, would imply a significantly more profound environmental legislation, - being much needed in the case of the rapid soy expansion. The difficulties associated with this have appeared clearly in the process of passing the Forest Code, due to the strong representation and efficient mobilization of rural interests within the Brazilian parliament. This suggests that the slowly increasing rural foothold within parliament and shifting ruling coalitions since the liberalizations of the $90^{\prime}$ es, per-se has become a significant obstacle to the implementation of socially oriented agricultural policies. Yet, the need emphasized by these neodevelopmentalist economists, for the state to establish a sufficient institutional framework in order to regulate the market, and furthermore facilitate activities with a high domestic value added, also stands in contrast to the very liberalized agricultural legislation since the 1990's, and would constitute an important goal in order to ensure a more socially sustainable rural development and a higher domestic spillover.

Moreover, the ten theses on neo-developmentalism also include a strong emphasis upon exchange rate policies and devaluation, with the goal of mitigating the negative structural effects of primary commodity dependence such as Dutch disease problems and to strengthen manufacturing capacity. In this regard, Bresser-Pereira suggests that the windfall profits which devaluation would result in for primary commodity exporters, be mitigated through an export-tax, which thereby would serve to level the differences 
between the potential of primary and secondary sectors for external revenue generation (BRESSER-PEREIRA, 2011). These ideas certainly constitute a more thorough response to the contemporary problems of structural dependency, of which the soy sector stands as a clear example, than any policies which have been effectuated by shifting governments for many decades. Whether policies based upon such un-tested neo-developmentalist visions can be seen as a significant move away from the present Brazilian agro-dependency and thereby work as a structural game-changer, stands as an open question to be answered, as the slowing Brazilian economy gives room to demands for alternative developmental perspectives.

\section{CONCLUSION}

From the earliest Brazilian developmental experiences, the goal of industrial modernization and the diminishing of agro-dependence has been partly bent towards ensuring continued export-performance, in order finance the developmentalist project. Consequentially, the supposed benefits of the modernization project were never extended to the rural working class; a situation with clear connotations to the pragmatism of agricultural policies of recent decades. Soy, which from its initial cultivation had been subsidized and regulated towards supplying the internal market, became of central importance for the development of Brazilian agriculture during the structural transformation and the neo-liberal turn of the country, in the 1990's. The conjunction of the disengagement of the state, the implementation of the Plano Real and the international opening of the country, wielded a clearly favorable edge towards export-oriented agriculture, within which the soy sector soon emerged to a clear position of primacy. On the internal political field, these developments are expressed by the alignment between rural and industrial bourgeoisie around a consensus of internationalization, which also turned the state into an active agent in ensuring the best possible position for Brazilian exportagriculture within the international panorama.

The continuity of the macroeconomic imperatives implied by the economic model adopted in the 1990's, throughout the subsequent PT administrations, meant that in a trade-off between socio-environmental concerns as opposed to continued external revenue generation, the later was chosen due to its higher degree of compatibility with the general economic course. As the issues of legalization of transgenic crops and the poor implementation of land reforms serve to demonstrate, in practice, the two Lula administrations have come to include many demands by agribusiness and rural bourgeoisie, 
ahead of smallholders and environmentally concerned segments. From a political perspective though, the strong divisions between the incumbent, and the rural factions in parliament, over the content of the new Forest Code, raise some clear questions as to how far the bond between large-scale agriculture and a leftist government can stretch. The policies toward the soy sector in recent decades have also been highly reflective of a feedback loop, between the increasing economic performance of the soy business and the sector's political influence, resulting in further economic concessions and increased export potential. Apart from the concerning features of economic dependency which this export concentration on a few raw materials implies, this trend also points toward a political dimension of dependency, in which the shifting structural imperatives of the world market change the composition of politically influential forces. Furthermore, from an economic perspective, the recent slump in the Brazilian economy also raises questions about the future capability of the primary commodity reliant model to ensure continued growth, and possibly more concerning - inclusive growth. The imprecise nature of the concept of neo-developmentalism means that the PT government's policies sometimes have been labeled with this, sometimes ascribed features of this, and sometimes defined in partial opposition to this. Upon decades when export-commodities such as soy have enjoyed a favorable treatment below the effectuated version of neo-developmentalism of the $21^{\text {st }}$ century, the evermore apparent negative aspects associated with a reliance upon raw materials, point towards the need to consider alternative developmental visions. In this regard, the different emphasis of the neo-developmentalism as it is expressed in the Ten Theses (2010), upon technological upgrading, productivity and industrial competitiveness in a long-term perspective, in which a more balanced role for primary commodities is envisaged, may draw increasing attention in the years to come.

\section{BIBLIOGRAPHY}

ALBANO, G P. \& DE SÁ, A.J. (2011) Globalizacão da Agricultura: Multinacionais no Campo Brasileiro. Revista de Geografia (UFPE). V. 28, No. 1 [online], P. 54- 80. Available from: http://www.revista.ufpe.br/revistageografia/index.php/revista/article/viewFile/459 /335. [Accessed: 12th October, 2013].

ALENCAR, K. 2003. Bancada ruralista define ofensiva no Congresso. Folha do São Paulo, [online] 14th November. Available from http://www.folha.uol.com.br/[Accessed: 20nd November 2013] 
BAN, C. 2012. Brazil's liberal neodevelopmentalism: New paradigm or edited orthodoxy?,Review of International Political Economy, 20:2, pp. 298-331, [online] DOI:10.1080/ 09692290.2012.660183, Available from: http://dx.doi.org/10.1080/09692290.2012.660183 [Accessed: February 27 $\left.{ }^{\text {th }}, 2014\right]$.

BERALDO, A.D. 2000.As Negociações Agrícolas e a Evolução do Comércio Agrícola Mundial, Revista de Politica Agricola 4 trimestre 2000 . p. 3-9. Brasília, Ministerio de Agricultura e do Abastecimento, [online] Available from:

http://www.conab.gov.br/conteudos.php?a=537\&t=2[Accessed: 2nd November, 2013].

BRAUN, M.B.S., LIMA, J.F. ,CARDOSO, R 2007 . Insersão Mundial e competitividade da Agricultura Brasileira, Informe Gepec - Vol. 11, $n^{0} 1$ Available from: http://erevista.unioeste.br/p.33-50. [Accessed: 21 th November 2013].

BRESSER-PEREIRA, L.C. 2011. O Brasil e o Novo Desenvolvimentismo, Interesse Nacional, April-Junho, pp.76-85, [online] Available from:

www.bresserpereira.org.br/view.asp?cod=4437[Accessed: February 12th, 2014].

CARVALHO, S. B. 2011. Primeiro mandato do governo Lula (2003-2006): uma revisão de literatura, II Seminário Dos Cursos das Ciencias Sociais Applicadas da Fecilcam, pp. 1-10, [online] available from: www.fecilcam.br[Accessed: Feb. 21 $\left.{ }^{\text {st }}, 2014\right]$.

CASSEL, A.; PATEL, R. 2003. Agricultural Trade Liberalization and Brazil's Rural Poor: Consolidating Inequality. POLICY BRIEF NO. 8 Food first, institute for food and development policy, [online] Available from:http://www.foodfirst.org/fr/node/267[Accessed: 20th November 2013].

CHRISTINA L. 2005. Lula assina Lei de Biossegurança com setevetos, Agência Brasil, [online] $3^{\text {rd }}$ March. Available from: http://agenciabrasil.ebc.com.br/[Accessed: $26^{\text {th }}$ October, 2013].

COELHO, C.N. 1999. A Politica Agrícola e o Endividamento do Setor Rural, Revista de Política Agrícola 4 trimestre 1999, pp. 10-32, Brasília, Ministério de Agricultura e do Abastecimento, [online] Available from: http://www.conab.gov.br/conteudos.php?a=537\&t=2[Accessed: $21^{\text {st }}$ October, 2013].

COELHO, M. 1991. O lugar das Ilusões - Brasília e os Paradoxos do Desenvolvimentismo, Lua Nova n. 23. [online] Available from: http://dx.doi.org/10.1590/S010264451991000100011(Scielo), [Accessed: February 16th, 2014].

DARIOT, D. 2007. A controvérsia da Soja Transgênica no Rio Grande do Sul, Thesis for Doctor degree in administration, Universidade Federal de Rio Grande do Sul, Escola de Administração. [online] p.1-196. Available from: $\quad$ http://hdl.handle.net/10183/17084 [Accessed 21 ${ }^{\text {st }}$ October 2013].

DELGADO, N. G. 2008. Liberalização Comercial e Agricultura Familiar No Brasil.A Experiência das Décadas de 1980 e 1990, Documento de Discussão No. 25, Grupo de Trabalho 
sobre Desenvolvimento e Meio Ambiente nas Américas [online] p.1-35. Available from: http://ase.tufts.edu/gdae/WGOverview.htm[Accessed: $8^{\text {th }}$ November 2013].

DE MELO, F. H. 1999. O Plano Real e a Agricultura Brasileira: Perspectivos, Revista de Economia Política, Vol 14, nr. 4 [online] p.146-155. Available from:

www.rep.org.br/PDF/76-9.PDF[Accessed 22th November 2013].

EMBRAPA. 2013. Soja em numerous, safra 2012/2013. [online] Available from: http:/ / www.cnpso.embrapa.br/index.php?cod pai=1\&op page $=294$

[Accessed: February 26 $\left.{ }^{\text {th }}, 2014\right]$.

ENGELMAN, S. I. \& GIL, A.D. 2012. A questão agrária no Brasil: a política agrária do governo Lula e a relação com o MST, Revista Eletrônica do CEMOP - No 02, pp.1-9, Available from: www.memoriaoperaria.org.br[Accessed: February 21 $\left.{ }^{\text {st }}, 2014\right]$.

FAOSTAT. 2014. Countries by commodity, soy, FOOD AND AGRICULTURE ORGANIZATION OF THE UNITED NATIONS, Available from: http://faostat.fao.org/site/339/default.aspx [Accessed: February 25th, 2014].

FOLHA. 2003. MP intensificacomércio de sementestransgênicas. Folha de São Paulo. [online] available from: http://www1.folha.uol.com.br/folha/dinheiro/ult91u75317.shtml [Accessed:20 $0^{\text {th }}$ November 2013].

FOLHA. 2009. Cresce concentração de terra no país, dir IBGE, Folha de São Paulo, [online]Available from: http://www1.folha.uol.com.br/fsp/dinheiro/fi0110200918.htm [Accessed: 2th November 2013].

FONSECA, P.C.D. ; HAINES, A. F. 2012. Desenvolvimentismo e política econômica: um cotejo entre Vargas e Perón, Economia e Sociedade, Campinas, v. 21, Número Especial, pp. 1043-1074. [online] Available from:

www.scielo.br/pdf/ecos/v21 nspe/v21nspea13.pdf[Accessed: February 13th, 2014].

FRANK, A. G. 1978. Dependent accumulation and underdevelopment. Basingstoke: The Macmillan Press.

GONCALVES, R. 2012. Novo Desenvolvimentismo e Liberalismo Enraizado, Serv. Soc. Soc., São Paulo, n. 112, pp. 637-671, [online] Available from: www.scielo.br/pdf/sssoc/n112/03.pdf[Accessed: 14th, february, 2014).

IBGE - Instituto Brasileiro de Geografia e Estatística. 2006. Agricultura Familiar, Primeiros Resultados, Brasil, Grandes Regiões e Unidades da Federacão. Ministério do Desenvolvimento Agrário/Ministério do Planejamento, Orçamento e Gestão. Brasília: Censo Agropecuário 2006. 
IBGE - Instituto Brasileiro de Geografia e Estadística 2013. Producão agrícola municipal, Lavoura temporária - área plantada, PA01[online] Available from: http://seriesestatisticas.ibge.gov.br [Accessed: $27^{\text {th }}$ October, 2013].

ITC - International Trade Centre. 2013. Trade map, International Trade Statistics, Trade statistics for international business development, [online] Available from: http://www.trademap.org/tradestat/Service SelCountry TS.aspx[Accessed: $\quad 10^{\text {th }}$ November, 2013].

MAÑAN, O. 2010. Revisitando el desarrollo:los nuevos imaginários son desafios civilizatórios, Revista Problemas del Desarrollo, 162 (41) pp. 5-30,[online] Available from: www.revistas.unam.mx[Accessed:february 10th, 2014].

MEDIDA PROVISÓRIA 113. 2003. MEDIDA PROVISÓRIA No 113 (temporary law nr. 133) $26^{\text {th }}$ March Presidência da República Casa Civil SubchefiaparaAssuntosJurídicos. [online] Available from:http://www.planalto.gov.br/ccivil 03/mpv/Antigas 2003/113.htm [Accessed: 22th November 2013].

MEDIDA PROVISÓRIA 131. 2003. MEDIDA PROVISÓRIA No 131 (temporary law nr. 131), $25^{\text {th }}$ September Presidência da República Casa Civil SubchefiaparaAssuntosJurídicos. [online] Available from:http://www.planalto.gov.br/ccivil 03/mpv/Antigas 2003/131.htm [Accessed: 22th November 2013].

MOLLO, M.L.R.; FONSECA, P.C.D.2013. Desenvolvimento e novo desenvolvimentismo: raízes teóricas e precisões conceituais, Revista de Economía política, vol. 33nr. 2 (131) pp. 222-239. [online] Available from:

http://www.scielo.br/pdf/rep/v33n2/a02v33n2.pdf[Accessed: February 11 ${ }^{\text {th }}$, 2014].

PRADO, M. E.2008. OS INTELECTUAIS E A ETERNA BUSCA PELA MODERNIZAÇÃO DO BRASIL: O SIGNIFICADO DO PROJETO NACIONALDESENVOLVIMENTISTA DAS DÉCADAS DE 1950-60 Historia Actual Online Núm. 15, pp. 19-27 [online] Available from: www.dialnet.unirioja.es/descarga/articulo/2546980.pdf [Accessed: February 10th, 2014].

PREBISH, R. 1950. The economic development of Latin America, economic commission for Latin America, United Nations Department OfEconomic Affairs, Lake Success, New York.

RIBEIRO, A. A. .2003. A polêmica sobre os transgênicos, Resenha Economia e Comércio / Desenvolvimento, Conjuntura Internacional, PUC Minas.[online] p.1-4. Available from: www.pucminas.br/ [Accessed: 21 ${ }^{\text {st }}$ October 2013].

RODRIGUES, R. 2001. O Papel do Setor Privado e os Novos Desafios do Abastecimento Nacional, Revista de Política Agrícola 1 trimestre 2001, p. 7-12. Brasília, Ministerio de Agricultura e do Abastecimento. [online] Available from:http:/ www.conab.gov.br/conteudos.php? $\mathrm{a}=537 \& \mathrm{t}=2$ [Accessed: $9^{\text {th }}$ October, 2013]. 
SALLUM, B. 1999. O Brasil sob Cardoso, neoliberalismo e desenvolvimentismo, Rev. Sociol. USP, S. São Paulo, 11(2) pp. 23-47. [online]Available from: www.revistas.usp.br/ts/article/view/12305[Accessed: February 12th, 2014].

SALLUM, B. 2003. Metamorfoses do estado brasileiro no final do século xx, RBCS Vol. 18 $n^{0}$. 52, pp.35-54 Available from: www.redalyc.org/articulo.oa?id=10705203 [Accessed: 15th, february, 2014].

SAMPAIO, P.A.2012. Desenvolvimentismo e neodesenvolvimentismo: tragédia e farsa, Serv. Soc. Soc., São Paulo, n. 112, pp. 672-688, [online] Available from: http://dx.doi.org/10.1590/S0101-66282012000400004 (Scielo), [Accessed: february 15th, 2014].

SCHLESINGER, S. 2008. Soja: el grano que sigue creciendo. Grupo de Trabajo sobre Desarrollo y Medio Ambiente en las Américas, Trabajo de Discusión No. 21. [online] pp. 1-23. Available from: http://ase.tufts.edu/gdae/WGOverview.htm. [Accessed: 13th October, 2013].

SISCU, J., DE PAULA, L.F. MICHEL, R.. 2005. Por que Novo-desenvolvimentismo?, (Introducão para) Novo-Desenvolvimentismo: um projeto nacional de crescimento com equidade social, pp.1-23, [online], Available from: http://dx.doi.org/10.1590/S0101-31572007000400001 (Scielo) [Accessed February 15th, 2014].

TAGLiAlEgNA, G. H. F.. 2005. Grupos de Pressão e a Tramitacão do Projeto de lei Biosseguranca no Congresso Nacional, TextosparaDiscussão. Consultoria Legislativa do Senado Federal, Coordenacão de Estudos (28) [online] p. 1-80. Available from: http://www.senado.gov.br/conleg/textos discussao.htm [Accessed: 23th October 2013].

Ten theses on new developmentalism. 2010. Brazilian Journal of Political Economy, vol. 32, $n^{\circ} 2$ (127), pp. 336-339.[online] Available from: www.tenthesesonnewdevelopmentalism.org [Accessed: February 18th, 2014].

VIGNA, E. 2007. Bancada ruralista: O MaionGrupo de Interesse no Congresso Nacional, Brasília, Instituto de EstudosSocioeconómicos, Outubro 2007 - Ano VII - no 12, [online] pp. 1-16 Available from: www.inesc.org.br/ [Accessed: $17^{\text {th }}$ October, 2013].

WARNKEN, P. 1999. Política e Programas - O Setor da Soja no Brasil. Revista de Política Agrícola 2 trimestre 1999, Brasília, Ministério de Agricultura e do Abastecimento, pp.41-85 [online]. Available at: http://www.conab.gov.br/conteudos.php?a $=537 \& \mathrm{t}=2$ [Accessed: $20^{\text {th }}$ October, 2013]. 